\title{
MODELOWANIE WPLYWU PARAMETRÓW EKSPLOATACYJNYCH NA STAN NAPREŻZENIA RUR GRUBOŚCIENNYCH W KOTŁACH O PARAMETRACH NADKRYTYCZNYCH
}

\begin{abstract}
W pracy przedstawiono przykłady modelowania procesów cieplno-mechanicznych zachodzących w rurach grubościennych podczas uruchamiania bloków energetycznych. Rozpatrzono przykłady elementów wykonanych ze stopu HR6W przeznaczonego na elementy urządzeń energetycznych o podwyższonych parametrach pracy. Omówiono zagadnienie wyznaczania pól temperatury i składowych stanu naprężenia na przykładzie rury grubościennej o średnicy zewnętrznej wynoszącej $540 \mathrm{~mm}$ i grubości ściany równej $127 \mathrm{~mm}$, która reprezentuje elementy bloków o nadkrytycznych parametrach pracy, projektowane z uwagi na kryterium wytrzymałości na pełzanie. Ciśnienie wewnątrz rury w warunkach pracy ustalonej wynosiło $31,4 \mathrm{MPa}$, a temperatura $610^{\circ} \mathrm{C}$. Skoncentrowano się na zagadnieniu oceny wpływu krótkotrwałych zmian temperatury podczas cykli uruchamiania bloku energetycznego na rozkłady zmiennej w czasie temperatury i związane $\mathrm{z}$ nimi naprężenia cieplne. Przedstawiono sposób modelowania uwzględniający możliwość oceny wpływu czasu rozruchu i niestabilności parametrów pary w tym okresie na przebieg lokalnych charakterystyk procesu odkształcania materiału. Ważne dla symulacji numerycznej właściwości materiałowe przyjmowano jako zależne od temperatury. Wyznaczono lokalne charakterystyki odkształcania wybranych punktów na powierzchni rury w postaci zależności pomiędzy odkształceniem i naprężeniem obwodowym. Wykazano istotny wpływ oscylacji temperatury występujących w warunkach rozruchu na zmienne w czasie pola naprężeń i odkształceń, sprzyjające powstawaniu zjawisk o zmęczeniowym charakterze.
\end{abstract}

Słowa kluczowe: zmęczenie cieplno-mechaniczne, symulacja numeryczna, rozruch kotłów energetycznych

\section{Wprowadzenie}

Ciągły wzrost parametrów pracy oraz konieczność większej dyspozycyjności uruchamianych i projektowanych obecnie bloków energetycznych, wynika-

\footnotetext{
${ }^{1}$ Autor do korespondencji/corresponding author: Krzysztof Wacławiak, Politechnika Śląska, ul. Krasińskiego 8, 40-019 Katowice, tel.: (32) 6034284, e-mail: krzysztof.waclawiak@polsl.pl

2 Jerzy Okrajni, Politechnika Śląska, e-mail: jerzy.okrajni@ polsl.pl
} 
jące zarówno ze względów ekologicznych, jak i dążenia do podniesienia ich sprawności, powoduje konieczność poszukiwania nowych materiałów spełniających kryteria wytrzymałościowe i bezpieczeństwo eksploatacji urządzeń narażonych na oddziaływanie coraz wyższej temperatury oraz rosnących obciążeń mechanicznych. Podstawowym kryterium oceny cech użytkowych materiałów przeznaczonych do pracy w urządzeniach bloków energetycznych jest ich wytrzymałość na pełzanie. Wobec tego projektowane i wytwarzane nowe stopy metali przeznaczone dla energetyki charakteryzują się coraz większą wytrzymałością na pełzanie, czego konsekwencją powinien być wzrost ich trwałości w warunkach długotrwałego oddziaływania ustalonych obciążeń o mechanicznym charakterze. Często jednak zmiany składu chemicznego oraz technologii wytwarzania nowego materiału oprócz zwiększenia wytrzymałości na pełzanie powodują także zmiany innych właściwości decydujących o jego zachowaniu się w warunkach technologii wytwarzania wykonywanych z niego elementów oraz ich użytkowania. Obserwuje się niekiedy większą skłonność do powstawania w nich wad podczas procesu spawania oraz obniżenie odporności na pękanie. Odmienne są również właściwości fizyczne nowych stopów w porównaniu z klasycznymi stalami stosowanymi od wielu lat w energetyce. Zespół tych cech okazuje się szczególnie istotny w warunkach oddziaływania zmiennych obciążeń. Dotyczy to zwłaszcza takich właściwości, jak współczynnik liniowej rozszerzalności i przewodności cieplnej. Ten ostatni zmienia się w zakresie od 11 do $31 \mathrm{~W} / \mathrm{m} \cdot \mathrm{K}$ w temperaturze od 20 do $600^{\circ} \mathrm{C}$. Rola tych właściwości rośnie z uwagi na ich wpływ na wielkość naprężeń cieplnych w warunkach rozruchu i wyłączania bloku energetycznego. Występujące wówczas zmienne, z dużą szybkością nierównomierne pola temperatury stanowią przyczynę pojawienia się zjawisk o zmęczeniowym charakterze. Materiały o wyższej przewodności i rozszerzalności cieplnej będą bardziej narażone na oddziaływanie procesów zmęczenia cieplno-mechanicznego.

Prognozowanie zachowania się i trwałości elementów poddanych zmęczeniu cieplno-mechanicznemu wymaga zastosowania metod analizy uwzględniających specyfikę ich właściwości materiałowych i warunków użytkowania. Wielkość oddziaływań cieplnych decydujących o intensywności procesów zmęczeniowych jest w tym przypadku zależna zarówno od warunków zewnętrznych, takich jak temperatura ośrodka, szybkość jej zmian w czasie i wartość ciśnienia, jak i właściwości fizycznych, od których zależą odkształcenia i naprężenia cieplne. Istotną rolę pełnią także zjawiska wymiany ciepła na powierzchni rozpatrywanych elementów. Opis współzależności pomiędzy zjawiskami o charakterze mechanicznym i cieplnym może się w takim przypadku opierać na zastosowaniu metod komputerowego modelowania, uwzględniającego opis przebiegu procesu wymiany ciepła oraz powstawania zmiennych w czasie pól temperatury i naprężeń cieplnych w elementach kotłów pracujących w energetyce. W pracy przedstawiono tego typu ujęcie na przykładzie rur grubościennych wykonanych ze stopu 
niklu HR6W przewidywanego do zastosowania na elementy grubościenne kotłów o parametrach nadkrytycznych.

\section{Modelowanie warunków rozruchu kotłów na przykładzie występujących w nich elementów w postaci rur grubościennych}

Charakterystyka obciążeń w warunkach jednego cyklu pracy elementów bloku energetycznego obejmuje okresy: uruchomienia, pracy przy ustalonej wartości temperatury pary i ciśnienia oraz okres odstawienia. Projektanci zakładają najczęściej, że podczas uruchamiania bloku temperatura i ciśnienie zmieniają się monotonicznie do wartości ustalonych, przyjmowanych jako nominalne parametry pracy instalacji. W celu ograniczenia wartości naprężeń związanych z oddziaływaniem nierównomiernego pola temperatury przyjmowane są dopuszczalne szybkości zmian temperatury w funkcji czasu. Ten przedział czasu w cyklu pracy można przybliżyć liniową zależnością pomiędzy zmienną temperaturą i czasem. W rzeczywistych warunkach podczas uruchamiania bloku występują chwilowe gwałtowne zmiany temperatury uwarunkowane procedurą włączania poszczególnych elementów instalacji, związane z działaniem systemu sterowania. Pojawiają się wówczas oscylacje temperatury pary [1-5]. Szybkość zmian temperatury pary w krótkich przedziałach czasu może osiągać znaczne wartości. Duża szybkość jej zmian powoduje powstawanie chwilowych znacznych gradientów temperatury na przekroju grubościennych elementów i towarzyszące tym gradientom zmiany naprężeń cieplnych. Na rysunku 1. przedstawiono różne przypadki możliwych zmian temperatury pary podczas uruchamiania bloku energetycznego. Przypadki te różnią się czasem rozruchu, decydującym o średniej prędkości zmian temperatury odniesionej do przedziału czasu obejmującego uruchomienie urządzeń bloku energetycznego. Zobrazowane na rys. 1. charakterystyki zmian temperatury pary w funkcji czasu potraktowano jako modelowe przybliżenie rzeczywistych warunków eksploatacji podczas stanów nieustalonych pracy bloku energetycznego. Przebiegi te obejmują również założone przedziały czasu, podczas których występują chwilowe oscylacje temperatury. Parametrami charakteryzującymi te oscylacje są: amplituda zmian temperatury i okres jej zmian. Tak założone modele możliwych przebiegów zmian temperatury pary podczas rozruchu miały na celu zbadanie wpływu zarówno średniej prędkości uruchamiania bloku energetycznego, jak i parametrów możliwych oscylacji temperatury na zmienny w czasie stan naprężenia w grubościennych elementach instalacji. Należy przy tym zauważyć, że liczba założonych oscylacji nie jest ściśle związana z rzeczywistymi warunkami użytkowania. Przyjęte warunki wymiany ciepła podczas rozruchu mają bowiem na celu sformułowanie wniosków o ogólnym charakterze, odnoszących się do ilościowego wpływu parametrów tych oscylacji na przebieg charakterystyk wytrzymałościowych elementów, w których występują. W rzeczywistych warunkach użytkowania oscylacje w poszczególnych rozruchach posiadają 
różne amplitudy, a ich liczba różni się dla poszczególnych nieustalonych okresów zmian temperatury.

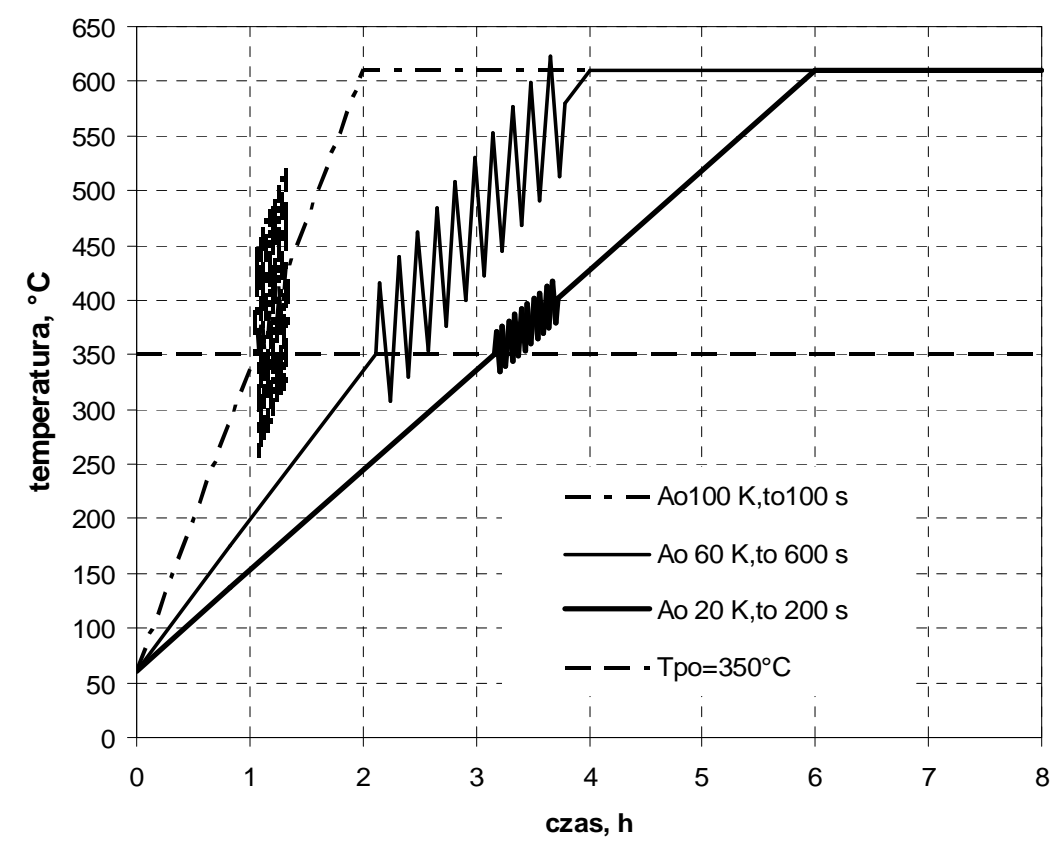

Rys. 1. Zmiana temperatury pary przyjęta w opisie konwekcji wymuszonej we wnętrzu rury dla przykładowych wariantów obliczeniowych

Fig. 1. Variation of steam temperature as a function of the time, assumed in forced convection inside the tube for exemplary calculated cases

W celu rozpatrzenia wpływu warunków uruchamiania bloku energetycznego na możliwość występowania w jego elementach procesów o zmęczeniowym charakterze założono różne wartości średniej szybkości zmian temperatury w czasie oraz przyjęto możliwość występowania oscylacji o różnej amplitudzie i zmieniającym się okresie. Jako parametry charakteryzujące przebieg poszczególnych rozruchów założono całkowity czas rozruchu $\mathrm{t}_{\mathrm{r}}$, temperaturę początku występowania oscylacji $\mathrm{T}_{\mathrm{po}}$, ich amplitudę $\mathrm{A}_{\mathrm{o}}$ oraz okres $\mathrm{t}_{\mathrm{o}}$.

Wielkości te były traktowane jako zmienne dla poszczególnych testów, w których przy zastosowaniu metody elementów skończonych wyznaczano zmienne w czasie rozkłady temperatury i naprężeń w rurze grubościennej. Rozpatrzono zagadnienie oceny zachowania się wybranej rury grubościennej ze stopu HR6W, zaprojektowanej do pracy w bloku energetycznym o parametrach nadkrytycznych - ciśnienie pary $31,5 \mathrm{MPa}$, temperatura $610^{\circ} \mathrm{C}$. Rozpatrywany element potraktowano jako rurę o nieskończonej długości, o równomiernym rozkładzie temperatury wzdłuż jej osi i na obwodzie. Zagadnienie wyznaczania pola temperatury i naprężeń było więc osiowosymetryczne. Średnica zewnętrzna rury 
wynosiła $534 \mathrm{~mm}$, a grubość ścianki $127 \mathrm{~mm}$. Elementy o takich wymiarach mogą występować w blokach o parametrach nadkrytycznych, z uwagi na wielkość występujących w nich obciążeń i temperatury oraz wytrzymałość na pełzanie stopu HR6W, który w przedstawionych rozważaniach potraktowano jako przykład materiału przeznaczonego do pracy w tych warunkach.

Ze względu na symetrię modelowano ćwiartkę rury. Utworzona siatka miała elementy o wielkości $5 \mathrm{~mm}$. Przeliczono 18 przykładów przedstawionych w tab. 1., uwzględniając: 3 czasy rozruchu (2, 4 i 6 h), 3 amplitudy oscylacji (20, 60 i $100 \mathrm{~K}$ ), 2 okresy oscylacji (200 i 600 s), liczbę oscylacji 10, z wyjątkiem 3 przypadków z czasem rozruchu wynoszącym $2 \mathrm{~h}$ i okresem oscylacji równym $600 \mathrm{~s}$ - wtedy liczba oscylacji wyniosła 5. Obliczenia wykonano przy zastosowaniu oprogramowania Ansys. Należy dodać, że analizowany najkrótszy czas rozruchu, wynoszący $2 \mathrm{~h}$, jest hipotetyczny i obecnie nie występuje w praktyce eksploatacyjnej. Służy jedynie wskazaniu, że taki przyspieszony rozruch prowadzi do wzrostu naprężenia w elemencie grubościennym.

Tabela 1. Zestawienie wariantów obliczeniowych

Table 1. A set of calculated cases

\begin{tabular}{|c|c|c|c|c|c|}
\hline Lp. & Oznaczenie & $\begin{array}{l}\text { Czas } \\
\text { rozruchu } t_{r}, h\end{array}$ & $\begin{array}{c}\text { Amplituda } \\
\text { oscylacji temperatury } \\
\mathrm{A}_{\circ}, \mathrm{K}\end{array}$ & $\begin{array}{l}\text { Okres oscylacji } \\
\text { temperatury } t_{0}, s\end{array}$ & Uwagi \\
\hline 1 & Ia $2 p$ & 2 & 20 & 200 & \\
\hline 2 & $\mathrm{Ib} 2 \mathrm{p}$ & 2 & 60 & 200 & \\
\hline 3 & Ic $2 p$ & 2 & 100 & 200 & \\
\hline 4 & Ialp & 2 & 20 & 600 & $\mathrm{~N}=5$ \\
\hline 5 & Ib1p & 2 & 60 & 600 & $\mathrm{~N}=5$ \\
\hline 6 & Ic1p & 2 & 100 & 600 & $\mathrm{~N}=5$ \\
\hline 7 & $\mathrm{IIa} 2 \mathrm{p}$ & 4 & 20 & 200 & \\
\hline 8 & IIb2p & 4 & 60 & 200 & \\
\hline 9 & IIc2p & 4 & 100 & 200 & \\
\hline 10 & IIa1p & 4 & 20 & 600 & \\
\hline 11 & IIb1p & 4 & 60 & 600 & \\
\hline 12 & IIc1p & 4 & 100 & 600 & \\
\hline 13 & IIIa2p & 6 & 20 & 200 & \\
\hline 14 & IIIb2p & 6 & 60 & 200 & \\
\hline 15 & IIIc $2 p$ & 6 & 100 & 200 & \\
\hline 16 & IIIa1p & 6 & 20 & 600 & \\
\hline 17 & IIIb1p & 6 & 60 & 600 & \\
\hline 18 & IIIc1p & 6 & 100 & 600 & \\
\hline
\end{tabular}




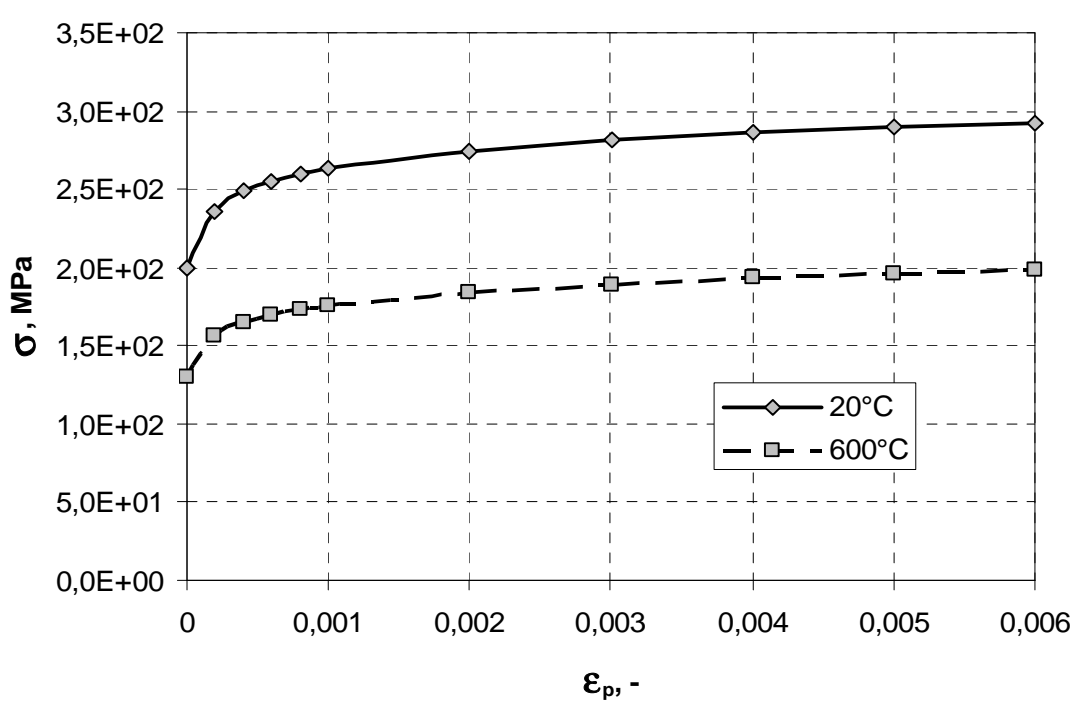

Rys. 2. Krzywe umocnienia stopu HR6W wyznaczone dla wybranych temperatur

Fig. 2. Strain-hardening curves of HR6W alloy determined for selected temperatures

Wykaz przyjętych założeń:

- gęstość stali $(\rho) 7840 \mathrm{~kg} / \mathrm{m}^{3}$,

- temperatura $(\mathrm{T})$ początkowa materiału rury $60^{\circ} \mathrm{C}$,

- temperatura początku występowania oscylacji $\mathrm{T}_{\mathrm{po}}=350^{\circ} \mathrm{C}$,

- liczba oscylacji $\mathrm{N}=10$ lub $5 \mathrm{w}$ trzech przypadkach,

- czas pracy ustalonej (niezmienności warunków brzegowych) $t_{u}=2 \mathrm{~h}$,

- ciśnienie (p) zmienne liniowo w czasie rozruchu od wartości 0 do $31,5 \mathrm{MPa}$,

- konwekcja swobodna na zewnątrz rury, opisana stałymi wartościami temperatury $50^{\circ} \mathrm{C}$ i współczynnika wnikania ciepła $(\alpha) 50 \mathrm{~W} / \mathrm{m}^{2} \cdot \mathrm{K}$,

- konwekcja wymuszona we wnętrzu rury, opisana stałą wartością współczynnika wnikania ciepła $(\alpha) 1000 \mathrm{~W} / \mathrm{m}^{2} \cdot \mathrm{K}$ oraz narastaniem temperatury od wartości początkowej do końcowej liniowo, z fragmentem występowania oscylacji o stałej szybkości wzrostu i spadku temperatury - o piłowym kształcie,

- typ modelu numerycznego - osiowosymetryczny,

- materiał - stop HR6W o właściwościach zależnych od temperatury: współczynniku rozszerzalności $(\beta)$, współczynniku przewodzenia ciepła $(\lambda)$, pojemności cieplnej właściwej $\left(c_{p}\right)$, module Younga (E), liczbie Poissona (v),

- umocnienie kinematyczne materiału,

- przedstawione $\mathrm{w}$ formie tabelarycznej krzywe umocnienia, uzyskane z prób rozciągania, w zależności od temperatury (przykłady ilustruje rys. 2., gdzie $\varepsilon_{\mathrm{p}}$ - odkształcenie plastyczne). 
Schemat przyjętych warunków brzegowych dla zagadnienia cieplnego i mechanicznego (przemieszczenia $\mathrm{u}_{\mathrm{x}}, \mathrm{u}_{\mathrm{y}}$ ) ilustruje rys. 3. Zaznaczono również punkt A w osi symetrii przekroju rury na powierzchni wewnętrznej oraz punkt B na powierzchni zewnętrznej rury. Dla tych punktów przedstawiono wyniki obliczeń, $w$ tym naprężenie obwodowe $\sigma_{\mathrm{o}}=\sigma_{\mathrm{x}} \mathrm{w}$ funkcji mechanicznego odkształcenia obwodowego $\varepsilon_{\mathrm{om}}$.

Rys. 3. Schematyczne przedstawienie przyjętych warunków brzegowych zagadnienia cieplno-mechanicznego

Fig. 3. The schematic representation of adopted boundary conditions for thermo-mechanical problem

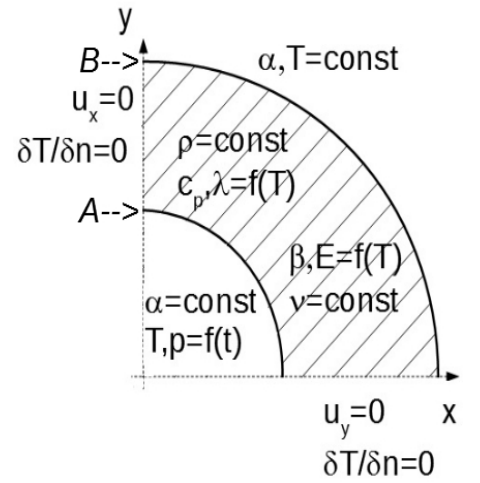

$\mathrm{Na}$ rysunku 4a przedstawiono przykłady charakterystyk obrazujących zmiany temperatury w przykładowych punktach rury grubościennej dla wybranego wariantu rozruchu. Na podstawie obliczonych rozkładów temperatury oraz wartości zmiennego w funkcji czasu ciśnienia wewnątrz rury wyznaczono rozkłady naprężeń. Rysunek 4b obrazuje zmiany w funkcji czasu naprężenia obwodowego wyznaczonego dla tego samego wybranego punktu i wariantu rozruchu. Charakterystykę tę przedstawiono na tle wykresu zmian temperatury punktu na powierzchni wewnętrznej w funkcji czasu.

Rozpatrując zagadnienie powstawania zjawisk zmęczeniowych w analizowanym elemencie, skoncentrowano się na przebiegu zmian naprężeń i odkształceń na powierzchni rury grubościennej. Wybrano w tym celu dwa punkty: A i B, na przekroju rury, położone na powierzchni wewnętrznej i zewnętrznej. W punktach tych analizowano przebieg zmian w czasie temperatury oraz składowych stanu naprężenia i odkształcenia. Stwierdzono, że z uwagi na większe wartości gradientów temperatury naprężenia cieplne wywołane jej oscylacjami osiągają większe wartości na powierzchni wewnętrznej rury. Na tej powierzchni również naprężenia obwodowe wywołane obciążeniami mechanicznymi - ciśnieniem przyjmują większe wartości w porównaniu $\mathrm{z}$ naprężeniami na powierzchni zewnętrznej. Rozpatrując odrębnie każdy z punktów położonych na powierzchni wewnętrznej, można zauważyć, że wyznaczone dla niego naprężenia obwodowe i osiowe wywołane nierównomiernym polem temperatury są takie same.

W pracy porównano zależności pomiędzy mechanicznymi odkształceniami i naprężeniami obwodowymi na powierzchni wewnętrznej rozpatrywanego elementu grubościennego, wyznaczone dla poszczególnych wariantów rozruchu. 
a)

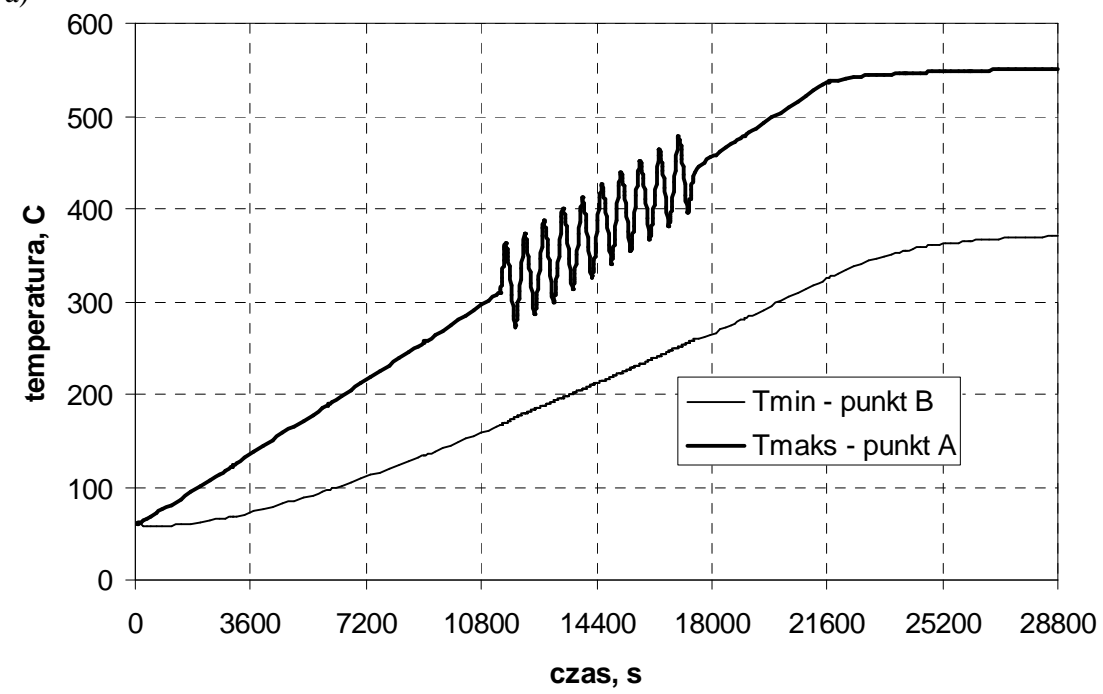

b)

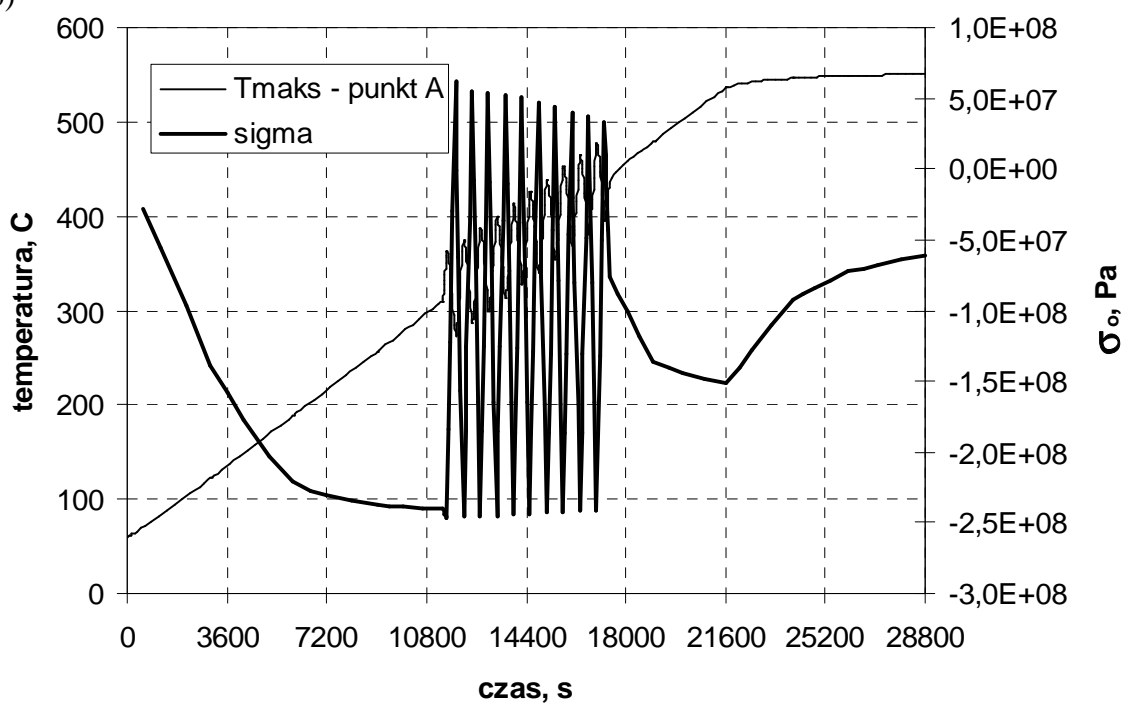

Rys. 4. Przebieg zmian temperatury w punkcie A w wybranym przypadku obliczeniowym: czas rozruchu $6 \mathrm{~h}$, amplituda oscylacji $60 \mathrm{~K}$, okres oscylacji $600 \mathrm{~s}$, wraz ze zmianami naprężenia obwodowego

Fig. 4. The variation of temperature in the point A for a selected computational case: startup time of $6 \mathrm{~h}$, oscillation amplitude of $60 \mathrm{~K}$, oscillation period of $600 \mathrm{~s}$, with the changes of circumferential stress

W pierwszej kolejności porównano ze sobą mechaniczne charakterystyki rozruchu wyznaczone dla tego samego czasu rozruchu i okresu oscylacji 200 s oraz ich różnych amplitud (rys. 5.). Wykresy przedstawione na rys. 5. wykazują istotny 


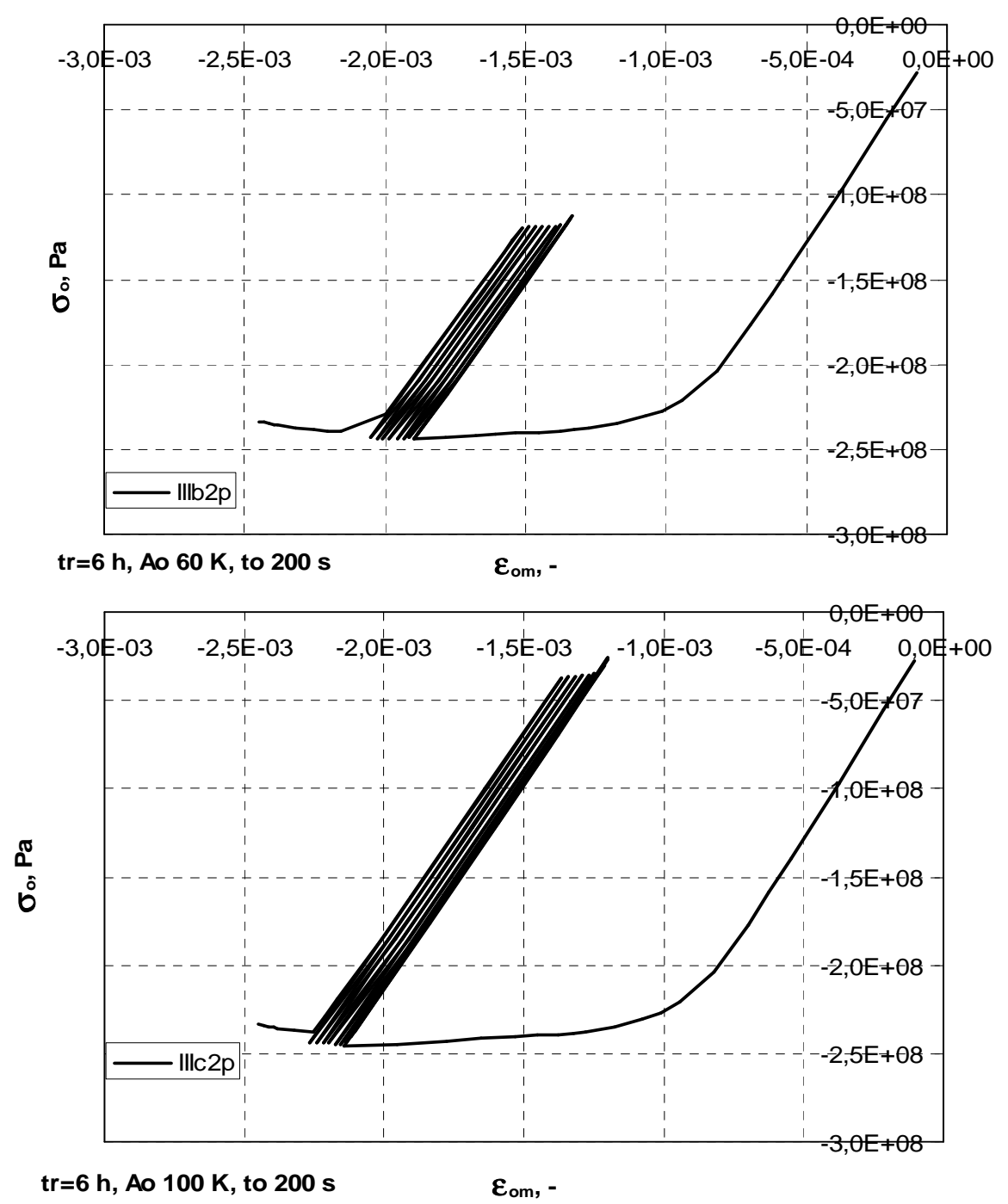

Rys. 5. Naprężenie obwodowe na powierzchni wewnętrznej rury (punkt A) w przypadku czasu rozruchu wynoszącego 6 h, okresu oscylacji 200 s i różnych amplitud oscylacji temperatury: 60 i $100 \mathrm{~K}$

Fig. 5. Circumferential stress at the inner surface of the tube (point A) for a following case: start-up time of $6 \mathrm{~h}$, oscillation period of $200 \mathrm{~s}$ and different oscillation amplitudes of temperature: 60 and $100 \mathrm{~K}$

wpływ amplitudy oscylacji na wartość naprężeń obwodowych, a w szczególności na zakres zmian tych naprężeń. Na tej podstawie można stwierdzić, że intensywność powstawania uszkodzeń o zmęczeniowym charakterze w elementach grubościennych kotłów o nadkrytycznych parametrach będzie zależała między innymi od wielkości amplitudy oscylacji temperatury. 


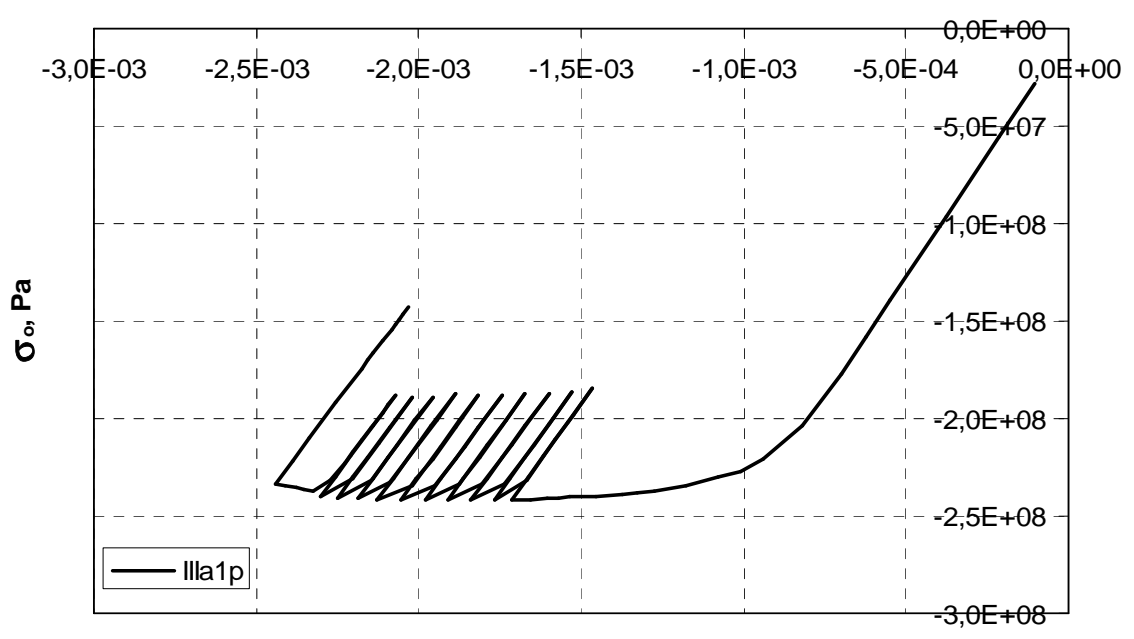

$\operatorname{tr}=6 \mathrm{~h}$, Ao $20 \mathrm{~K}$, to $600 \mathrm{~s} \quad \varepsilon_{\text {om }},-$

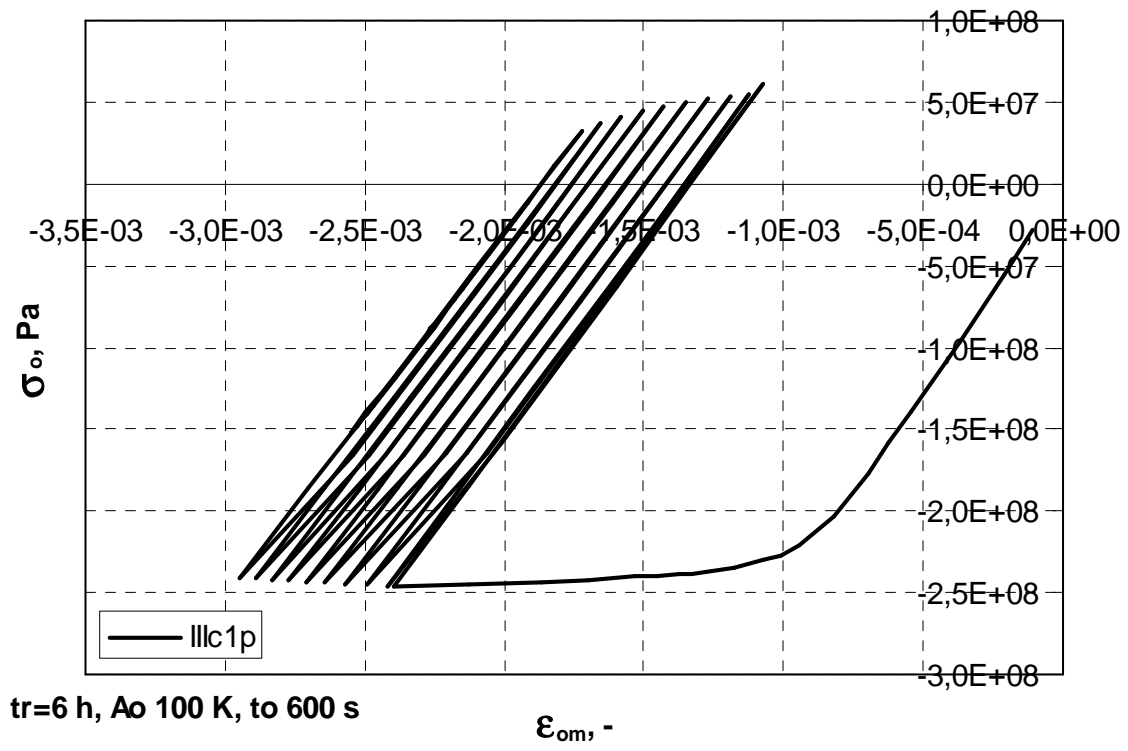

Rys. 6. Wpływ amplitudy oscylacji (20 i $100 \mathrm{~K}$ ) na naprężenie obwodowe na powierzchni wewnętrznej rury (punkt A) w przypadku czasu rozruchu wynoszącego $6 \mathrm{~h}$ i okresu oscylacji $600 \mathrm{~s}$

Fig. 6. Effect of oscillation amplitude (20 i $100 \mathrm{~K})$ on circumferential stress at the inner surface of the tube (point A) for a following case: start-up time of $6 \mathrm{~h}$ and oscillation period of $600 \mathrm{~s}$

Podobne stwierdzenie można sformułować na podstawie analizy wykresów na rys. 6., na którym przedstawiono charakterystyki wyznaczone dla dłuższego okresu oscylacji - 600 s. Porównując charakterystyki z rys. 5. i 6., zauważa się 

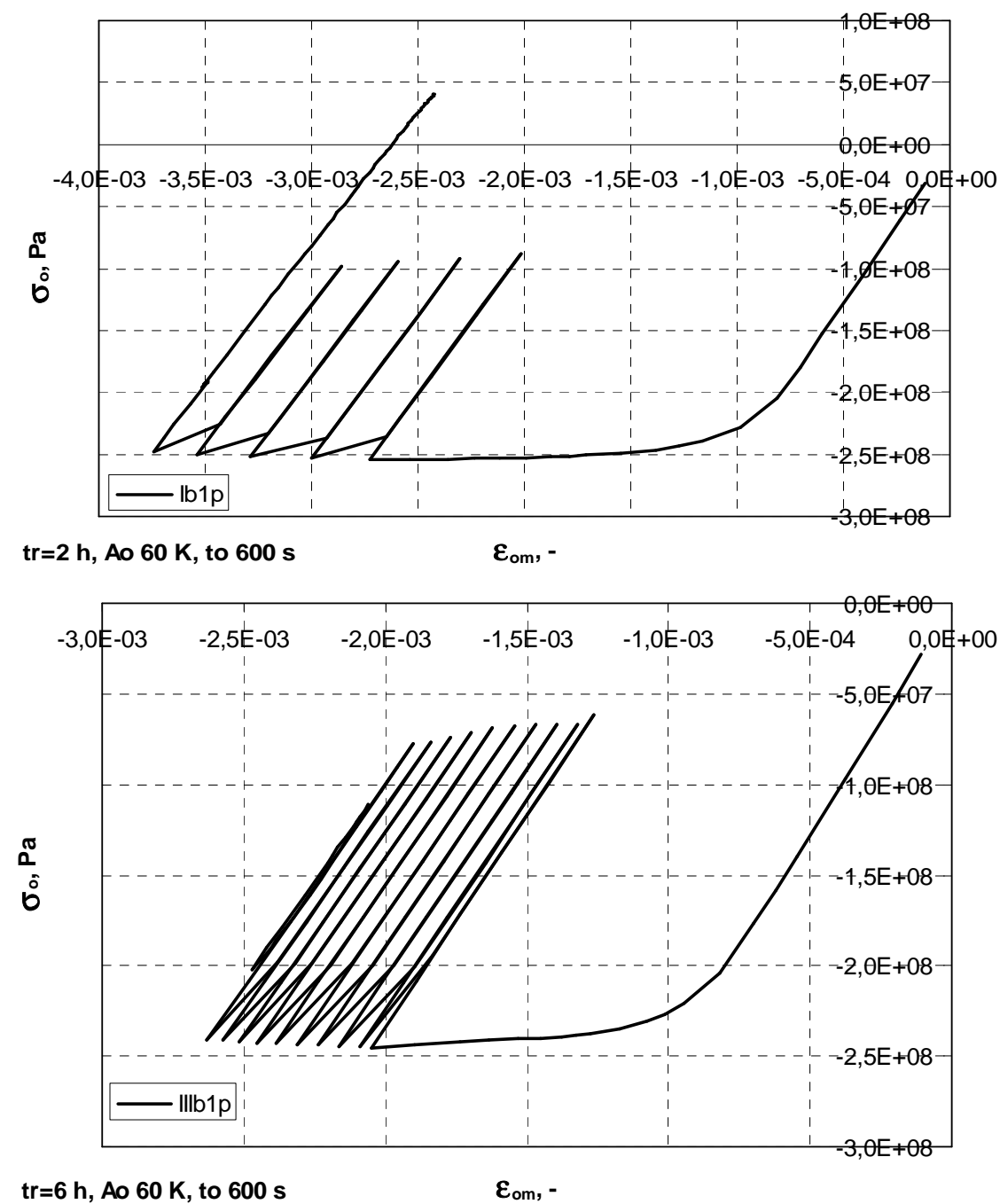

Rys. 7. Wpływ czasu rozruchu (2 i $6 \mathrm{~h}$ ) na naprężenie obwodowe na powierzchni wewnętrznej rury (punkt A) w przypadku okresu oscylacji $600 \mathrm{~s}$ amplitudy oscylacji temperatury $60 \mathrm{~K}$

Fig. 7. Effect of start-up time ( 2 and $6 \mathrm{~h}$ )on circumferential stress at the inner surface of the tube (point A) for a following case: oscillation period of $600 \mathrm{~s}$ and oscillation temperature of $60 \mathrm{~K}$

dwie kolejne prawidłowości. Po pierwsze, zwiększenie okresu oscylacji może prowadzić do wzrostu zakresu zmiennych naprężeń. Naprężenia zmieniają przy tym swój znak podczas poszczególnych cykli oscylacyjnego wzrostu i spadku temperatury. Po drugie, na powierzchni rozpatrywanej rury grubościennej największa wartość mechanicznego odkształcenia całkowitego zależy od wartości 
amplitudy oscylacji. Efekt ten staje się bardziej wyraźny w przypadku dużych okresów oscylacji i można go interpretować jako skutek kumulacji odkształceń trwałych w poszczególnych cyklach zmian temperatury i związanych z nią naprężeń.

Najbardziej istotnym czynnikiem, decydującym o największej wartości odkształcenia $w$ danym cyklu uruchomienia bloku, jest czas rozruchu $t_{r}$ (rys. 7.). Jest on związany z szybkością nagrzewania powierzchni wewnętrznej rury grubościennej i ma wpływ na chwilowy „stopień nierównomierności rozkładu temperatury" mierzony przy powierzchni jej gradientem. Decyduje zatem o rozkładzie naprężeń cieplnych, które równoważą się w całej objętości rury. W przypadku oscylacji temperatury obszar, w którym równoważą się naprężenia, jest ulokowany w pobliżu powierzchni rury i zależy od amplitudy oscylacji oraz ich okresu.

$\mathrm{Na}$ podstawie przeprowadzonej oceny charakteru zmian stanu naprężenia w zależności od rodzaju obciążeń i położenia punktu, w którym jest analizowany przebieg procesu odkształcania, należy zauważyć, że przebieg ten zależy od relacji pomiędzy charakterystykami zmiennych w czasie obciążeń mechanicznych i obciążeń cieplnych zdeterminowanych polem temperatury, a w analizie procesów zmęczeniowych przebiegi zmian takich wielkości, jak naprężenie, odkształcenie i temperatura należy traktować w sposób lokalny.

\section{Podsumowanie}

Wielkość oddziaływań decydujących o procesie powstawania uszkodzeń $\mathrm{w}$ rozpatrywanych elementach grubościennych urządzeń energetycznych jest związana nie tylko ze zmianami parametrów pracy instalacji, takich jak ciśnienie i temperatura oraz szybkość jej zmian w cyklu pracy bloku energetycznego, lecz zależy również od właściwości fizycznych materiałów, z których są wykonane. Należą do nich między innymi przewodność, pojemność oraz dyfuzyjność cieplna, decydujące o przebiegu zmian temperatury w objętości rozpatrywanych elementów, w tym o wielkości jej gradientów wpływających na wartości odkształceń oraz naprężeń cieplnych. Stwierdzenie to jest szczególnie istotne w przypadku stopu HR6W, ponieważ jego wysoka wytrzymałość i trwałość w warunkach pełzania wiążą się z niekorzystnie niską przewodnością cieplną, decydującą o wielkości wspomnianych gradientów. Dodatkowo ten niekorzystny wpływ jest wzmacniany oddziaływaniem wyższej rozszerzalności cieplnej w porównaniu z konwencjonalnymi stalami stosowanymi w energetyce.

Analiza przebiegu zmiennych w funkcji czasu naprężeń i odkształceń w rozpatrywanej rurze grubościennej wykazała, że występowanie chwilowych oscylacyjnych zmian temperatury $\mathrm{w}$ warunkach uruchamiania bloku energetycznego może prowadzić do powstawania zjawisk zmęczeniowych zachodzących w elementach grubościennych wykonanych z materiałów o właściwościach fizycznych sprzyjających powstawaniu w nich naprężeń cieplnych. Zjawiska o takim charak- 
terze można analizować przy użyciu modelowania komputerowego, w tym metody elementów skończonych umożliwiającej wyznaczenie zmiennej w funkcji czasu temperatury, naprężeń i odkształceń dla założonych zależnych od temperatury właściwości fizycznych materiału.

Przedstawione w opracowaniu rozważania odnoszą się do wybranego materiału oraz charakterystyk rozruchu zbliżonych swoimi parametrami do ich możliwych rzeczywistych przebiegów podczas tego etapu pracy instalacji. Już na tym etapie rozważań, które mają charakter głównie metodyczny, można zauważyć, że istotność zjawisk o charakterze zmęczeniowym rośnie wraz ze wzrostem parametrów pracy urządzeń instalacji energetycznych. W przypadku tego rodzaju instalacji ważna jest procedura ich uruchamiania, w której szczególną rolę pełni czas rozruchu. W procedurach takich należy również wziąć pod uwagę możliwość wystąpienia oscylacji temperatury, których parametry będą decydowały o zmęczeniu materiału na powierzchni elementów instalacji. Obecnie istnieje możliwość prowadzenia szczegółowych analiz zjawisk o charakterze zmęczeniowym już na etapie projektowania instalacji energetycznych. W analizach tego rodzaju istotne są dane odnoszące się tak do zmiennych w funkcji czasu parametrów pracy bloków energetycznych, jak i zależnych od temperatury właściwości materiałowych.

Przedstawione opracowanie obejmuje ocenę przebiegu zmiennych w funkcji czasu naprężeń i odkształceń w wybranym elemencie dla wybranych modelowych przebiegów rozruchu bloku energetycznego oraz założonych właściwości fizycznych i danych odnośnie do przebiegu umocnienia materiału, wyznaczonych w statycznej próbie rozciągania. Przyjęto również stały współczynnik przejmowania ciepła na podstawie norm projektowania naczyń ciśnieniowych [6]. W dalszej kolejności należy wziąć pod uwagę eksperymentalnie wyznaczone właściwości zmęczeniowe rozpatrywanego materiału, a w szczególności wpływ temperatury na przebieg cyklicznych procesów odkształcania i trwałość w warunkach zmęczenia cieplno-mechanicznego [7-11]. Należy również rozpatrzeć wpływ zmienności współczynnika przejmowania ciepła w zależności od parametrów pary i czasu na rozkłady temperatury w rozpatrywanych elementach $[4,5]$. Zagadnienia te będą przedmiotem kolejnych analiz.

Podziękowania: Praca została wykonana $\mathrm{z}$ wykorzystaniem Infrastruktury PLGrid. Obliczenia zostały przeprowadzone na superkomputerze Prometheus w ACK Cyfronet AGH.

\section{Literatura}

[1] Farragher T.P., Scully S., O’Dowd N.P., Leen S.B.: Development of life assessment procedures for power plant headers operated under flexible loading scenarios, Int. J. Fatigue, 49 (2013) 50-61. 
[2] Farragher T.P., Scully S., O’Dowd N.P., Leen S.B.: Thermomechanical analysis of pressurized pipe under plant conditions, ASME J. Pressure Vessel Technol., 135 (2013) 011204-1-9.

[3] Okrajni J., Twardawa M.: Local strains that lead to the thermo-mechanical fatigue of thick-walled pressure vessels, Mater. Performance Characterization ASTM Int., 2 (2014) 244-261.

[4] Okrajni J., Twardawa M.: Boundary conditions in models of power plant components under thermal loading, Arch. Mater. Sci. Eng., 62 (2013) 28-35.

[5] Okrajni J., Twardawa M.: Influence of a variable in time heat transfer coefficient on stresses in models of power plant components, ASME J. Pressure Vessel Technol., 136 (2014) 041602-1-6.

[6] PN-EN 12952-4:2002.

[7] Bressers J., Remy L. (eds.): Fatigue under Thermal and Mechanical loading, Kluwer Academic Publishers, Netherlands 1996.

[8] Hähner P., Rinaldi C., Bicego V., Affeld E., Brendel T., Andersson H., Beck T., Klingelhöffer H., Kühn H.-J., Köster A., Laveday M., Marchionni M., Rae C.: Research and development into a European code-of-practice for strain-controlled thermo-mechanical fatigue test, Int. J. Fatigue, 30 (2008) 372-381.

[9] Sehitoglu H.: Thermal and thermo-mechanical fatigue of structural alloys, [in:] Fatigue and Fracture ASTM Handbook, 19 (2008) 527-556.

[10] Okrajni J., Plaza M.: Simulation of the fracture process of materials subjected to low-cycle fatigue of mechanical and thermal character, J. Mater. Proc. Technol., 53 (1995) 311-318.

[11] Okrajni J., Junak G., Marek A.: Modelling of the deformation process under thermomechanical fatigue conditions, Int. J. Fatigue, 30 (2008) 324-329.

\section{MODELING OF RELATION BETWEEN OPERATION PARAMETERS OF SUPER-CRITICAL POWER BOILERS AND STRESS FIELDS OF THICK-WALLED TUBES}

\footnotetext{
S u m m a r y

The examples of simulation of thermo-mechanical processes which undergo during start-up of commercial power boilers in thick-walled tubes have been presented. The tubes were made of nickel alloy HR6W. This material will be used for thick-walled elements of future boilers with raised operation parameters. The determination of temperature distribution and components of stress state was carried out for the tube with an outer diameter of $540 \mathrm{~mm}$ and wall thickness of $127 \mathrm{~mm}$. The analysed heavy wall tube represents the elements of super-critical unit designed due to creep strength. The pressure inside the tube, under steady-state conditions, was $31.4 \mathrm{MPa}$ and temperature was equal to $610^{\circ} \mathrm{C}$. The investigations were focused on assessment of the effect of transient changes in temperature during start-up cycles of power unit on distributions of time-dependent temperature and thermal stresses. The method of modeling that allows to assess the effect of start-up time and instability of steam parameters on the local characteristics of the material deformation. The important material properties for the numerical simulation were assumed in relation to the temperature. The local characteristics of deformation of selected points lying on tube surface in
} 
a form of relations between strain and circumferential stress were determined. It has been shown that temperature change oscillations under start-up of boiler has an important effect on the time-dependent stress and strain distributions, intensifies the fatigue phenomena.

Keywords: thermomechanical fatigue, numerical simulation, start-up of power boilers

DOI: $10.7862 / \mathrm{rm} .2018 .09$

Otrzymano/received: 07.01.2018

Zaakceptowano/accepted: 22.01.2018 